\title{
Natural Products against Sand Fly Vectors of Leishmaniosis: A Systematic Review
}

\author{
Michela Pugliese (D), Gabriella Gaglio, Annamaria Passantino * $\mathbb{C}^{\mathbb{D}}$, Emanuele Brianti and Ettore Napoli \\ Department of Veterinary Sciences, University of Messina, 98168 Messina, ME, Italy; mpugliese@unime.it (M.P.); \\ ggaglio@unime.it (G.G.); ebrianti@unime.it (E.B.); enapoli@unime.it (E.N.) \\ * Correspondence: passanna@unime.it; Tel.: +39-0039-90-6766742
}

Citation: Pugliese, M.; Gaglio, G.; Passantino, A.; Brianti, E.; Napoli, E. Natural Products against Sand Fly Vectors of Leishmaniosis: A Systematic Review. Vet. Sci. 2021, 8 , 150. https://doi.org/10.3390/ vetsci 8080150

Academic Editor: Valentina Foglia Manzillo

Received: 11 June 2021

Accepted: 28 July 2021

Published: 30 July 2021

Publisher's Note: MDPI stays neutral with regard to jurisdictional claims in published maps and institutional affiliations.

Copyright: (c) 2021 by the authors. Licensee MDPI, Basel, Switzerland. This article is an open access article distributed under the terms and conditions of the Creative Commons Attribution (CC BY) license (https:// creativecommons.org/licenses/by/ $4.0 /)$.

\begin{abstract}
Leishmaniosis is a vector-borne disease transmitted to animals and humans by the bite of blood-sucking phlebotomine sand flies. These small insects play a crucial role in the diffusion of the disease. To date, the sole strategy recognized for the prevention of leishmaniosis is the use of topical repellent compounds against sand fly bites. Several synthetic insecticides and repellents have been developed; however, the wide and unprejudiced use of these formulations have led to the loss of their effectiveness and the development of resistance phenomena. Moreover, some of these synthetic repellents have severe detrimental effects on the environment and could represent a serious threat to both animal and human health. Recently, an increased interest in the research on alternative approaches to sand fly control has been expressed. In this study, we systematically reviewed the efforts of the scientific community to individuate a phytochemical alternative for the control of sand fly species recognized as vectors of Leishmania spp. Based on literature research using different electronic databases, a total of 527 potentially relevant studies were screened and narrowed down to a final 14 eligible scientific reports. Our analysis suggests that although there is a rapidly growing body of literature dedicated to botanical insecticides and repellents against sand fly vectors of Leishmania spp., much of this literature is limited to in vitro studies conducted in laboratory conditions, and only a few of them investigated the repellency of plant-based products. These studies highlighted that natural compounds display a really short period of action and this significantly limits the use of these products as an alternative to chemical-based repellents.
\end{abstract}

Keywords: sand fly; vectors; vector borne diseases; repellence; natural products; plant-based products

\section{Introduction}

Leishmaniosis is a zoonotic disease regarded as one of the most common vector-borne diseases (VBDs) throughout the world [1]. To understand the relevance of this VBD, it is enough to underline that the WHO (2010) [1] estimated about 50,000 to 90,000 new cases of leishmaniosis annually, which occurs in humans worldwide and remains one of the top parasitic diseases with a potential for outbreak and mortality. Leishmaniosis is transmitted to animals and humans through the bite of blood-sucking phlebotomine sand flies (Diptera: Psychodidae) [2] belonging to the genera Phlebotomus and Lutzomyia in the Old and New World, respectively $[3,4]$. These insects play a crucial role in the epidemiology of the disease, being the only proven vectors of L. infantum; their bites are the only way to transmit the disease [2]. Phlebotomine sand flies are small insects (1.5-3.5 $\mathrm{mm}$ in length) and only the female needs to feed on blood in order to gain all the nutrients necessary for egg production [2]; these blood meals are taken on many vertebrate hosts (i.e., reptiles, birds, and mammals) since they are considered opportunistic and general feeders [5]. The domestic dog, Canis lupus familiaris, has been regarded as the reservoir of the infection for a long time [6]; however, other domestic and wild mammals have recently been recognized as co-protagonists in the maintenance of the disease [5]. Over the last few decades, many efforts to limit the spread of leishmaniosis have been made and several strategies have 
been formulated to improve its control and the prevention; some of these efforts were focused on the treatment or the control of the causative agents (i.e., vaccination), but the majority were focused on the control of the vectors, which currently represents the sole strategy for the prevention of the disease [7]. In the past, control measures aimed at reducing vector populations in the environment by means of insecticides have been tried; however, the environmental treatment against the adult stages has a transitory effect and is unsustainable in the long term for several technical and economic reasons [7]. While the control of immature stages of sand flies is considered unpractical due to the wide variety of microhabitats (e.g., tree roots and holes, animal burrows, leaf litter, manure, holes, and crevices in walls) favorable for the breeding of larvae and pupae [4,7], the economic cost of this kind of approach is also inconvenient when compared to its real benefit.

So far, the sole strategy recognized for the prevention of leishmaniosis is the use of topical repellent compounds in different formulations for individual protection against the sand fly bites $[7,8]$. The concept of repellence is well-defined in the etymology of its name- the term "repellent" derives from the ancient Latin "repellere", which means "to reject". A repellent can be defined as a volatile substance, natural or synthetic, which induces an insect to move towards an opposite direction, nullifying the attractive stimulus represented by an animal or a human [9-11]. The concept of repellence was developed by the first humans many years ago; in fact, since the dawn of history, humans have had to drive insects away from habitation and for this purpose, they have had to develop a different strategy. The use of smoke, typically obtained from the burning of plants, was undoubtedly the first and the most common method used for repelling insects [12]; equally pioneering was the use of plant and plant-based products on animals and humans for insect repellence when applied onto the hair, skin, or clothes [12].

In many parts of the world, plant-derived products (i.e., essential oils or plant extracts) were traditionally used to repel and kill insects [13]. Plant-based insecticides tend to have a broad spectrum of activity and are normally safe for both animals and the environment [14]. Indeed, crude plant-extract and essential oils were widely used as insecticides up to the beginning of WWII in the 1940s when organic laboratory-synthesized insecticides became available $[15,16]$; in particular, dichloro-diphenyl-trichloro-ethane (DDT) was introduced as a repellent and insecticide in 1939 [12]. However, this compound has negative effects on the environment and human health, and has been banned in most countries of the world [17]. Nevertheless, DDT is still routinely used in some developing countries, most of them in Africa, to fight mosquitoes that carry malaria [18]; in India, this compound is used to control the adult stage of sand flies [19] despite demonstrating a high resistance to DDT [20].

Pyrethroids have been developed in Europe since the 1930s [21], showing minimal toxicity for mammalian; these products are the synthetic analog of pyrethrum. Pyrethrum is a natural oil derived from the flowers of the plant Chrysanthemum cinerariifolium [15]. Among the synthetic analogs of pyrethrum, the permethrin, first synthesized in the United States in 1972 [22] and initially registered for agricultural use in 1979, became a cornerstone for the prevention and control of important VBDs in a few years' time. The use of this molecule in different formulations is effective in controlling the vectors of malaria [2], as well as useful against the sand fly vectors of Leishmania [3,23,24]. From these precursors, several synthetic insecticides and repellents have been developed in the last decades; used alone or in combination, they have contributed to the protection of humans and animals against insects and the related VBDs. However, the wide and unprejudiced use of these formulations have led to the loss of their effectiveness and the development of resistance phenomena $[25,26]$. Moreover, considering the restrictions on the use of some insecticides and repellents because of their effects on both animal and human health [27] as well as on the environment [28], the search for natural repellents as an alternative to chemicalbased products has been pushed forward in the last years. This colossal turnaround, intended as a return to the use of plant-based products against arthropods, has brought 
about extensive research into ticks [25,26,29] and mosquitoes [13,30-37], while the use of plant-based products against sand flies has been less investigated.

In this study, we systematically reviewed the efforts of the scientific community to individuate a phytochemical alternative for the control of sand fly species recognized as vectors of Leishmania spp.

\section{Material and Methods}

\subsection{Data Sources and Search Strategy}

To meet the objectives of this article, all the eligible studies on the repellency effects of plant-based products against sand flies published from January 1990 to June 2020 were systematically searched using electronic databases, which include PubMed, Medline, Google Scholar, and BMJ (British Medical Journal), using the following Medical Subjects and keywords:

Plant [Title/Abstract], plants [Title/Abstract], extract [Title/Abstract], extracts [Title/Abstract], essential oil [Title/Abstract], essential oils [Title/Abstract], Insect repellent [Title/Abstract], repellent [Title/Abstract], repellence [Title/Abstract], repellency [Title/Abstract] and sand flies or sand fly [Title/Abstract]; moreover, a manual search was conducted using references from retrieved studies.

\subsection{Inclusion and Exclusion Criteria}

For the present systematic review, we only considered and included publication that met the following inclusion criteria:

1. The publication was in English (i.e., at least the abstract);

2. The full text was available;

3. Inspected the effects of plant-based products against sand fly vectors of Leishmania spp.;

4. Reported the percentage of repellency and/or complete protection time and/or insecticide efficacy;

5. Were original studies conducted in the laboratory and/or field conditions.

Moreover, we excluded the following from the present review: articles without an available full text, books, documents, republished data, conference papers, reviews, systematic reviews, and meta-analyses; articles that were conducted on non-target insect species.

All the articles identified were screened for title and abstract independently by two different authors (EN, MP); for those articles considered suitable, based on title and abstract and that met the inclusion criteria and did not fall within the exclusion criteria, the full text were further evaluated independently by the two authors to be included in systematic review.

\section{Results}

The available literature was searched, as reported above, and a total of 511 potentially relevant studies were identified in electronic databases; 16 were obtained from a manual search according to the references of the retrieved studies and in grey literature. Figure 1 presents the flowchart of the preliminary assessment from which we extrapolated the number of scientific reports on plant-based products tested against sand flies. In particular, the majority of scientific reports were identified on Pubmed and Google Scholar (i.e., 295 and 200, respectively), followed by Medline and BMJ (i.e., 11 and 5, respectively). 


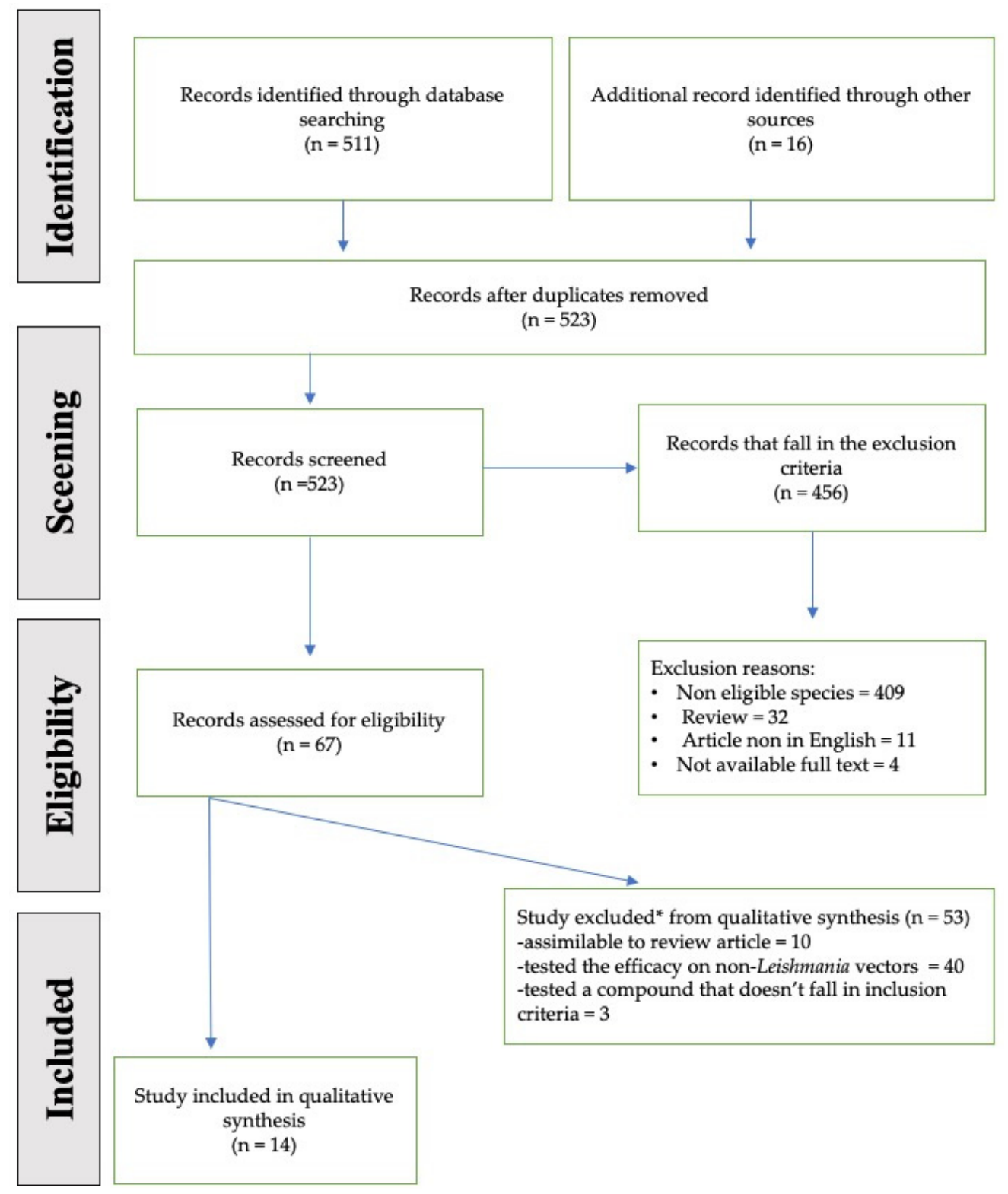

*excluded after full paper evaluation

Figure 1. Scientific reports that fully satisfy the inclusion criteria.

Among the 527 potentially relevant studies, we identified 4 replicates; 456 that fell under the exclusion criteria or did not fulfill the inclusion criteria, 409 of which were not focused on the target species; 32 were reviews; 11 articles were not in English; and 4 did not have a full text available. Therefore, a total of 67 full texts were evaluated for inclusion in the review. Figure 1 illustrates the flow of the study selection process. Of the 67 articles evaluated, 53 were excluded after the evaluation of the full text because 10 were similar to a review article, 41 tested their efficacy on non-Leishmania vectors, 3 tested a compound that did not fall under the inclusion criteria (i.e., 1 pheromone, 1 nanostructure hydrogels, and 1 KBR 3023 or icardin); a total of 14 articles included in the present manuscript were about plant-based products against sand flies.

Table 1 summarizes the scientific reports that fulfilled the inclusion criteria. In particular, seven were conducted in vitro [38-43], while only five were conducted in vivo [44-48] in laboratory conditions, and two explored both conditions [49-51]. As reported in Figure 2A, the number of scientific reports was unevenly distributed in the study period (i.e., from 
1990 to 2020), although a positive trend was observed. In particular, the majority of the publications $(11 / 14 ; 78.6 \%)$ were produced in the last decade of the time window analyzed.

Table 1. The table summarizes the characteristics of study examined considering the plant formulations and their efficacy.

\begin{tabular}{|c|c|c|c|c|c|c|c|c|c|}
\hline & Scientific Name & $\begin{array}{l}\text { Common } \\
\text { Name }\end{array}$ & Formulation & $\begin{array}{c}\mathrm{mg} / \mathrm{mL} \\
\text { or } \%\end{array}$ & $\begin{array}{c}\text { Efficacy } \\
\text { after } 72 \mathrm{~h} \\
(\%)\end{array}$ & $\begin{array}{l}\text { Study } \\
\text { Type }\end{array}$ & $\begin{array}{l}\text { Sand Fly } \\
\text { Species }\end{array}$ & $\begin{array}{c}\text { Leishmania } \\
\text { Species }\end{array}$ & Ref \\
\hline \multirow{2}{*}{ I } & Citrus medica & Green Lemon & \multirow{2}{*}{ Essential oil } & 0.01 & $70 \%$ & Vivo & Lu. youngi & L. infantum & \multirow{2}{*}{ [49] } \\
\hline & Citrus medica & Green Lemon & & 0.01 & $78 \%$ & Vitro & Ph. papatasi & L. infantum & \\
\hline \multirow{2}{*}{ II } & Azadiracha indica & Neem oil & \multirow{2}{*}{$\begin{array}{l}\text { Hexane- } \\
\text { extracted } \\
\text { oil }\end{array}$} & $5 \%$ & $100 \%$ & \multirow{2}{*}{ Vivo } & \multirow{2}{*}{ Ph. papatasi } & \multirow{2}{*}{ L. infantum } & \multirow{2}{*}{ [44] } \\
\hline & Azadiracha indica & Neem oil & & $2 \%$ & $96.6 \%$ & & & & \\
\hline III & Azadiracha indica & Neem oil & $\begin{array}{l}\text { Hexane- } \\
\text { extracted } \\
\text { oil }\end{array}$ & $2 \%$ & $96.6 \%$ & Vivo & Ph. papatasi & L. infantum & [45] \\
\hline \multirow{2}{*}{ IV } & \multirow{2}{*}{ Azadiracha indica } & \multirow{2}{*}{ Neem oil } & \multirow{2}{*}{ Essential oil } & 0.01 & $75 \%$ & \multirow{2}{*}{ Vitro } & \multirow{2}{*}{ Ph. papatasi } & \multirow{2}{*}{ L. infantum } & \multirow{2}{*}{ [38] } \\
\hline & & & & 0.02 & $82 \%$ & & & & \\
\hline \multirow{2}{*}{$\mathrm{V}$} & Antonia ovata & - & \multirow{2}{*}{$\begin{array}{l}\text { Aqueous } \\
\text { extract }\end{array}$} & 223 & $80 \%$ & \multirow{2}{*}{ Vitro } & \multirow{2}{*}{ Lu. longipalpis } & \multirow{2}{*}{ L. infantum } & \multirow{2}{*}{ [39] } \\
\hline & Derris amazonica & - & & 212 & $66.7 \%$ & & & & \\
\hline \multirow{4}{*}{ VI } & \multirow{4}{*}{ Allium sativum } & \multirow{4}{*}{ Garlic } & \multirow{4}{*}{ Essential oil } & 0.005 & $40 \%$ & \multirow{4}{*}{ Vivo } & \multirow{4}{*}{ Ph. papatasi } & \multirow{4}{*}{ L. infantum } & \multirow{4}{*}{ [46] } \\
\hline & & & & 0.01 & $65 \%$ & & & & \\
\hline & & & & 0.10 & $90 \%$ & & & & \\
\hline & & & & 1.00 & $95 \%$ & & & & \\
\hline VII & Mirtus communis & Myrtle & Essential oil & 1.9 & $62.2 \%$ & Vivo & Ph. papatasi & L. infantum & [47] \\
\hline \multirow{8}{*}{ VIII } & \multirow{2}{*}{ Azadirachta indica } & Neem oil & & $2 \%$ & $96.28 \%$ & Vitro & & & \\
\hline & & & & $5 \%$ & $98.26 \%$ & & ic & & \\
\hline & & & & $2 \%$ & $95.13 \%$ & Viтn & Ph. Ortentalts & L. aonooant & \\
\hline & Melia azedarach & $\begin{array}{l}\text { Persian lilac } \\
\text { oil }\end{array}$ & extracted & $5 \%$ & $96.20 \%$ & Vioo & & & {$[50]$} \\
\hline & & & oil & $2 \%$ & $95 \%$ & & & & \\
\hline & & & & $5 \%$ & $95 \%$ & Vitro & Ph heroeroti & $I$ maior & \\
\hline & Azadirachta indica & Neem oil & & $2 \%$ & $92 \%$ & vitur & 17. vergetrit & L. Trujor & \\
\hline & & & & $5 \%$ & $92 \%$ & & & & \\
\hline
\end{tabular}

\begin{tabular}{|c|c|c|c|c|c|c|c|c|c|}
\hline \multirow{8}{*}{ IX } & Hyptis suaveolens & Pignut & \multirow{8}{*}{ Essential oil } & \multirow{8}{*}{ n.r. } & \multirow{8}{*}{$\begin{array}{c}\text { No } \\
\text { efficacy }\end{array}$} & \multirow{8}{*}{ Vivo } & \multirow{8}{*}{ Lu. migonei } & \multirow{8}{*}{ L. infantum } & \multirow{8}{*}{ [48] } \\
\hline & Pimenta racemosa & $\begin{array}{l}\text { West Indian } \\
\text { bay tree }\end{array}$ & & & & & & & \\
\hline & $\begin{array}{l}\text { Monticalia } \\
\text { imbricatifolia }\end{array}$ & Saccoloma & & & & & & & \\
\hline & Espeletia schultzii & Frailejón & & & & & & & \\
\hline & $\begin{array}{l}\text { Plectharanthus } \\
\text { amboincus }\end{array}$ & $\begin{array}{l}\text { Cuban } \\
\text { oregano }\end{array}$ & & & & & & & \\
\hline & Piper marginatum & Cake bush & & & & & & & \\
\hline & $\begin{array}{l}\text { Pseudognaphalium } \\
\text { calciforum }\end{array}$ & $\begin{array}{l}\text { Ladies' } \\
\text { tobacco }\end{array}$ & & & & & & & \\
\hline & $\begin{array}{l}\text { Cinnamomun } \\
\text { zeylancium }\end{array}$ & Cinnamon & & & & & & & \\
\hline
\end{tabular}


Table 1. Cont.

\begin{tabular}{|c|c|c|c|c|c|c|c|c|c|}
\hline & Scientific Name & $\begin{array}{l}\text { Common } \\
\text { Name }\end{array}$ & Formulation & $\begin{array}{c}\mathrm{mg} / \mathrm{mL} \\
\text { or } \%\end{array}$ & $\begin{array}{c}\text { Efficacy } \\
\text { after } 72 \mathrm{~h} \\
(\%)\end{array}$ & $\begin{array}{l}\text { Study } \\
\text { Type }\end{array}$ & $\begin{array}{l}\text { Sand Fly } \\
\text { Species }\end{array}$ & $\begin{array}{c}\text { Leishmania } \\
\text { Species }\end{array}$ & Ref \\
\hline \multirow{15}{*}{$x$} & \multirow{5}{*}{$\begin{array}{l}\text { Eucalyptus } \\
\text { staigeriana }\end{array}$} & \multirow{5}{*}{ Eucalyptus } & \multirow{15}{*}{ Essential oil } & 0.3 & $1.7 \%$ & \multirow{15}{*}{ Vitro } & \multirow{15}{*}{ Lu. longipalpis } & \multirow{15}{*}{ L. infantum } & \multirow{15}{*}{ [40] } \\
\hline & & & & 0.6 & $11.7 \%$ & & & & \\
\hline & & & & 1.2 & $32.34 \%$ & & & & \\
\hline & & & & 2.5 & $65.81 \%$ & & & & \\
\hline & & & & 5 & $100 \%$ & & & & \\
\hline & $\begin{array}{l}\text { Eucalyptus } \\
\text { citriodora }\end{array}$ & $\begin{array}{c}\text { Lemon } \\
\text { Scented } \\
\text { eucalyptus }\end{array}$ & & 2 & $7.1 \%$ & & & & \\
\hline & \multirow{5}{*}{$\begin{array}{l}\text { Eucalyptus } \\
\text { globosus }\end{array}$} & \multirow{5}{*}{$\begin{array}{l}\text { Southern blue } \\
\text { gum }\end{array}$} & & 4 & $23.8 \%$ & & & & \\
\hline & & & & 6 & $45.2 \%$ & & & & \\
\hline & & & & 8 & $70 \%$ & & & & \\
\hline & & & & 10 & $100 \%$ & & & & \\
\hline & & & & 2 & $3.1 \%$ & & & & \\
\hline & & & & 4 & $10.6 \%$ & & & & \\
\hline & Eucalyptus & Southern blue & & 6 & $25.8 \%$ & & & & \\
\hline & globosus & gum & & 8 & $47.64 \%$ & & & & \\
\hline & & & & 10 & $96.47 \%$ & & & & \\
\hline \multirow{9}{*}{ XI } & \multirow{3}{*}{ Tagetes minuta } & \multirow{3}{*}{$\begin{array}{l}\text { Mexican } \\
\text { marigold }\end{array}$} & \multirow{3}{*}{$\begin{array}{l}\text { Methanol } \\
\text { extract }\end{array}$} & 2.5 & $50 \%$ & \multirow{9}{*}{ Vitro } & \multirow{9}{*}{ Ph. duboscqi } & \multirow{9}{*}{ L. major } & \multirow{9}{*}{ [41] } \\
\hline & & & & 5 & $63 \%$ & & & & \\
\hline & & & & 10 & $100 \%$ & & & & \\
\hline & & & & 2.5 & $60 \%$ & & & & \\
\hline & Acalypha fruticosa & Birch-Leaved & Acetate & 5 & $48 \%$ & & & & \\
\hline & & & extract & 10 & $100 \%$ & & & & \\
\hline & \multirow{3}{*}{$\begin{array}{c}\text { Tarchonanthus } \\
\text { camphoratus }\end{array}$} & \multirow{3}{*}{$\begin{array}{l}\text { Camphor } \\
\text { bush }\end{array}$} & \multirow{3}{*}{$\begin{array}{l}\text { Methanol } \\
\text { extract }\end{array}$} & 2.5 & $10 \%$ & & & & \\
\hline & & & & 5 & $10 \%$ & & & & \\
\hline & & & & 10 & $20 \%$ & & & & \\
\hline \multirow{12}{*}{ XII } & \multirow{12}{*}{$\begin{array}{c}\text { Monticalia } \\
\text { greenmaniana }\end{array}$} & \multirow{12}{*}{ Saccoloma } & \multirow{4}{*}{$\begin{array}{l}\text { Essential- } \\
\quad \text { oil }\end{array}$} & 0.001 & $95 \%$ & \multirow{12}{*}{ Vitro } & & & \\
\hline & & & & 0.1 & $100 \%$ & & & & \\
\hline & & & & 0.2 & - & & & & \\
\hline & & & & 0.3 & - & & & & \\
\hline & & & & 0.1 & $100 \%$ & & & & \\
\hline & & & Methanol & 1 & $100 \%$ & & & & \\
\hline & & & extract & 10 & - & & Lu. migonei & L. infantum & [42] \\
\hline & & & & 100 & - & & & & \\
\hline & & & & 0.1 & $100 \%$ & & & & \\
\hline & & & Aqueous & 1 & $100 \%$ & & & & \\
\hline & & & extract & 10 & - & & & & \\
\hline & & & & 100 & - & & & & \\
\hline
\end{tabular}


Table 1. Cont.

\begin{tabular}{|c|c|c|c|c|c|c|c|c|c|}
\hline & Scientific Name & $\begin{array}{l}\text { Common } \\
\text { Name }\end{array}$ & Formulation & $\begin{array}{c}\mathrm{mg} / \mathrm{mL} \\
\text { or } \%\end{array}$ & $\begin{array}{c}\text { Efficacy } \\
\text { after } 72 \mathrm{~h} \\
(\%)\end{array}$ & $\begin{array}{l}\text { Study } \\
\text { Type }\end{array}$ & $\begin{array}{l}\text { Sand Fly } \\
\text { Species }\end{array}$ & $\begin{array}{l}\text { Leishmania } \\
\text { Species }\end{array}$ & Ref \\
\hline \multirow{8}{*}{ XIII } & \multirow{5}{*}{ Argeratina jahnii } & \multirow{5}{*}{ Snakeroot } & $\begin{array}{c}\text { Methanol } \\
\text { extract }\end{array}$ & \multirow[t]{2}{*}{$0.1 / 1 / 10$} & \multirow[t]{2}{*}{$\begin{array}{c}\text { No } \\
\text { efficacy }\end{array}$} & \multirow{8}{*}{ Vitro } & \multirow{8}{*}{ Lu. migonei } & \multirow{8}{*}{ L. infantum } & \multirow{8}{*}{43} \\
\hline & & & $\begin{array}{l}\text { Aqueous } \\
\text { extract }\end{array}$ & & & & & & \\
\hline & & & \multirow{3}{*}{ Essential oil } & 0.1 & $22 \%$ & & & & \\
\hline & & & & 1 & $100 \%$ & & & & \\
\hline & & & & 10 & $100 \%$ & & & & \\
\hline & \multirow{3}{*}{$\begin{array}{l}\text { Argeratina } \\
\text { pichinchensis }\end{array}$} & \multirow{3}{*}{$\begin{array}{l}\text { Fragrant } \\
\text { snakeroot }\end{array}$} & $\begin{array}{l}\text { Methanol } \\
\text { extract }\end{array}$ & & & & & & \\
\hline & & & $\begin{array}{l}\text { Aqueous } \\
\text { extract }\end{array}$ & & & & & & \\
\hline & & & Essential oil & & & & & & \\
\hline \multirow{9}{*}{ XIV } & \multirow{5}{*}{$\begin{array}{l}\text { Cymbopogon } \\
\text { citratus }\end{array}$} & \multirow{5}{*}{ Lemon grass } & & 0.125 & $51.3 \%$ & \multirow{9}{*}{ Vitro } & \multirow{9}{*}{ Ph. duboscqi } & \multirow{9}{*}{ L. major } & \multirow{9}{*}{ [51] } \\
\hline & & & & 0.25 & $59.1 \%$ & & & & \\
\hline & & & & 0.50 & $89.1 \%$ & & & & \\
\hline & & & & 0.75 & $87.7 \%$ & & & & \\
\hline & & & Essential oil & 1.00 & $100 \%$ & & & & \\
\hline & \multirow{4}{*}{ Tagetes minuta } & \multirow{4}{*}{$\begin{array}{l}\text { Mexican } \\
\text { marigold }\end{array}$} & & $\begin{array}{c}0.125 \\
0.25\end{array}$ & $\begin{array}{l}21.5 \% \\
46.8 \% \\
\end{array}$ & & & & \\
\hline & & & & 0.50 & $52.2 \%$ & & & & \\
\hline & & & & 0.75 & $76 \%$ & & & & \\
\hline & & & & 1.00 & $88.9 \%$ & & & & \\
\hline
\end{tabular}

Figure 2B presents the geographical origin of the studies reported herein. Out of six continents, $42.86 \%$ (i.e., 6/14) of the studies were produced in South America, with three in Venezuela [42,43,49] and three in Brazil [39,40,48]; of the $28.57 \%$ (i.e., 4/14), three were produced in India $[38,44,45]$ and one in Iran [47]; $21.43 \%$ of the studies were produced in Africa (i.e., two in Kenya [41,51] and one in Ethiopia [50]); only one was produced in Europe (i.e., in Italy) [46].

Going into the specifics of the plant-based products used in the scientific studies, a big variety of the plants tested belongs to twenty-five different species and eleven different families.

Table 2 summarizes the plant and the relative family. In particular, the majority of the species belong to the Asteraceae (i.e., 9/25; 36\%) and the Myrtaceae (i.e., 5/25; 20\%) families. However, the majority (i.e., $28.57 \%$ ) of the studies were focused on the Meliacee family, and in particular, on $A$. indica (i.e., the neem oil). The botanical product is related not to the geographic origin where the study was performed but to the sand fly species. In fact, the plants that were mainly tested from Africa and Asia were A. indica, against Ph. orientalis [50] and $P h$. papatasi $[38,44,45,47]$, respectively. While in South America, the largest number of plants was tested, all against the sand fly species belonging to the genus Lutzomyia. The efficacy of the different formulations of these plant-based products was tested; in particular, eight studies were used in essential oils [38,40,42,43,46-49,51], three in hexane-extracted oil [44,45,50], and four in ethyl acetate, methanol, or aqueous extract [39,41-43]. 


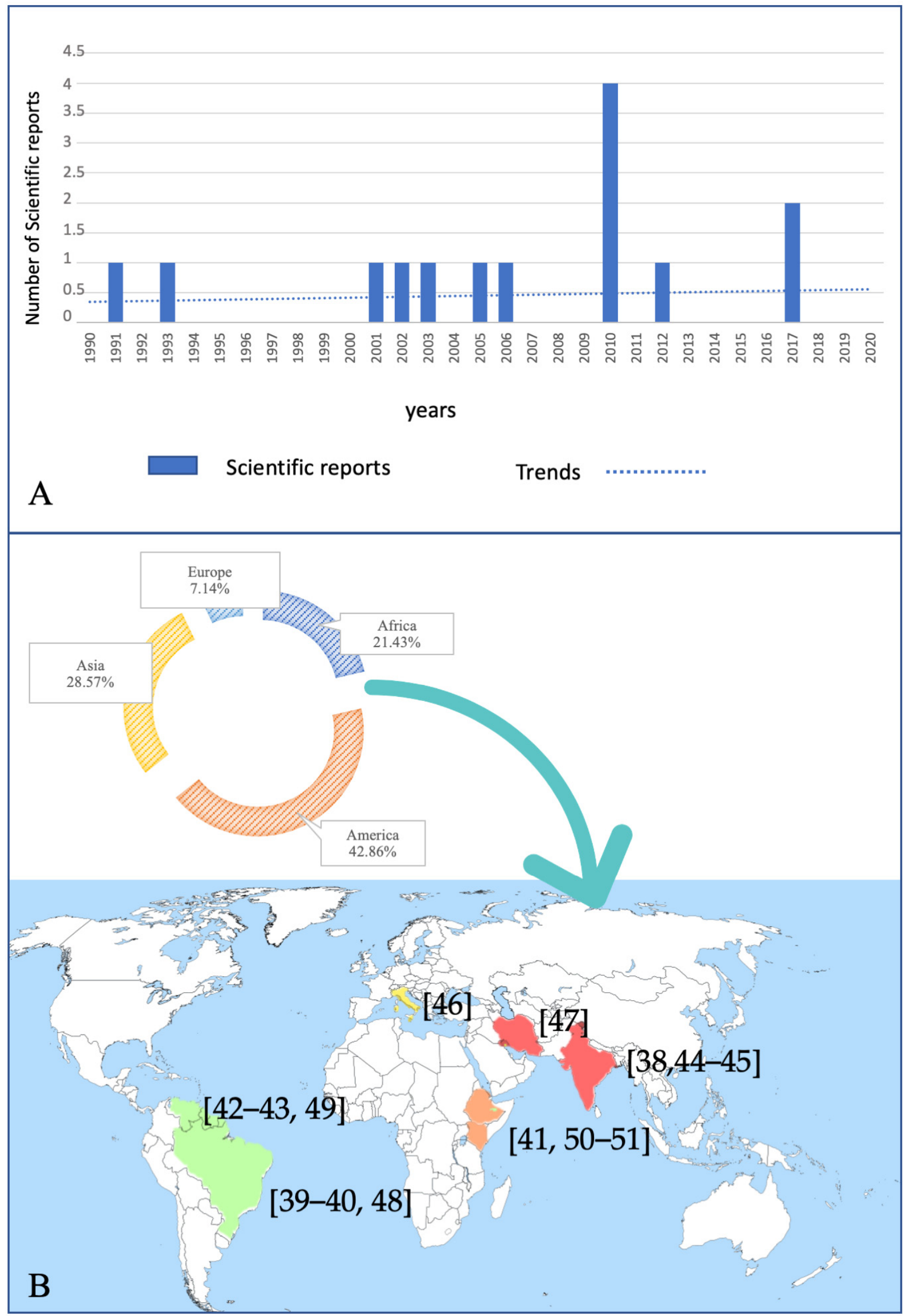

Figure 2. Number of scientific reports in the study period (A) and their geographical origin (B). 
Table 2. Botanical products tested as insecticide and/or repellent in the studies analyzed.

\begin{tabular}{|c|c|c|c|}
\hline & Family & Scientific Name & Number of Scientific Reports \\
\hline I & Amaryllidaceae & $\begin{array}{c}\text { Allium sativum } \\
\text { Monticalia imbricatifolia } \\
\text { Espeletia schultzii } \\
\text { Pseudognaphalium calciforum } \\
\text { Cinnamomun zeylancium }\end{array}$ & $\begin{array}{l}1 \\
1 \\
1 \\
1 \\
1\end{array}$ \\
\hline II & Asteraceae & $\begin{array}{c}\text { Tagetes minuta } \\
\text { Tarchonanthus camphoratus } \\
\text { Monticalia greenmaniana } \\
\text { Argeratina jahnii } \\
\text { Argeratina pichinchensis }\end{array}$ & $\begin{array}{l}2 \\
1 \\
1 \\
1 \\
1\end{array}$ \\
\hline III & Citrus & Citrus medica & 2 \\
\hline IV & Euphorbiacee & Acalypha fruticosa & 1 \\
\hline $\mathrm{V}$ & Labiatae & Plectharanthus amboincus & 1 \\
\hline VI & Lamiaceae & Hyptis suaveolens & 1 \\
\hline VII & Loganiacaceae & $\begin{array}{c}\text { Antonia ovata } \\
\text { Derris amazonica }\end{array}$ & $\begin{array}{l}1 \\
1\end{array}$ \\
\hline VIII & Meliacee & $\begin{array}{l}\text { Melia azedarach } \\
\text { Azadirachta indica } \\
\text { Myrtus communis }\end{array}$ & $\begin{array}{l}2 \\
4 \\
1\end{array}$ \\
\hline IX & Myrtacae & $\begin{array}{l}\text { Pimenta racemosa } \\
\text { Eucalyptus staigeriana } \\
\text { Eucalyptus citriodora } \\
\text { Eucalyptus globosus }\end{array}$ & $\begin{array}{l}1 \\
1 \\
1 \\
1\end{array}$ \\
\hline$x$ & Piperaceae & Piper marginatum & 1 \\
\hline XI & Poaceae & Cymbopogon citratus & 1 \\
\hline
\end{tabular}

The majority of the studies herein reported investigate the insecticide effects of plantbased products (i.e., 8/14; 57.28\%); however, especially in the last decades of the timewindow considered, the attention of researchers was focused mainly on the repellent activity of plant-based products against sand flies (i.e., 6/11, 54.54\%) [39,45-47,50,51].

The efficacy of the tested compounds, which needs at least $24 \mathrm{~h}$ to reach the maximum in all the selected studies, normally persists only for a limited period, although only a few studies consider this aspect.

All the plant-based products investigated as repellents showed high efficacy (i.e., $>80 \%$ ), although these products demonstrated a short period of action. For instance, Rojas and Scorza (1991) [49] reported a repellency timespan of $30 \mathrm{~min}$ (i.e., 70\% of efficacy) for C. medica against Lu. youngi, while the repellency of P. caeruleocanum and C. zylancnicum against Lu. mingonei [39] was longer (i.e., $3 \mathrm{~h}$ ). The neem oil, at concentrations of $2 \%$ and $5 \%$, showed a repellency of $99.57 \%$ against $\mathrm{Ph}$. Orientalis, and $99.2 \%$ (i.e., 5\%) and 92\% (i.e., 2\%) against Ph. bergoroti [50] for $8 \mathrm{~h}$ and $24 \mathrm{~min}$, respectively. Myrtle essential oils of T. minuta and C. citratus demonstrated repellent activity against $P h$. dubosqui of $88.89 \%$ and $100 \%$, respectively, for $3 \mathrm{~h}$.

The effect of plant-based products, as an insecticide or as a repellent, was assessed on seven different sand fly species; in particular, three of the species belong to the genus Lutzomyia (i.e., Lu. longipalpis, Lu. mingonei, and Lu. youngi, all regarded as vectors of L. infantum) and four to the genus Phlebotomus (i.e., Ph. papatasi, the main vector of L. infantum; Ph. dubosqui and Ph. bergoti, vectors of L. major; and Ph. orientalis, vector of L. donovani). 


\section{Discussion}

This study systematically reviewed the available literature published between 1990 and 2020 on the effect-insecticide or repellent—of plant-based products against the sand fly species recognized as vectors of Leishmania spp., thus providing evidence that only a few attempts were made to use natural products against these vectors.

Starting from their development before WWII in the 1940s [15,16], the use of synthetic insecticides and repellents has significantly increased in both animals and humans in order to prevent losses directly or indirectly related to blood-sucking arthropods and the related VBDs (i.e., lives, economic resources and money used to cure the related diseases) [26]. The use of a large number of synthetic compounds has inevitably led to the creation of arthropod species that are resistant to these chemicals [26]; moreover, it has been stated that this wide use of chemical products represents a serious threat to both human and animal health (i.e., through residuals in foods and feeds) as well as a risk for the environment and the preservation of biodiversity $[15,52,53]$.

Therefore, the use of the so-called "green chemistry", based on the use of microbial and plant products, selected metabolites as well as green synthesized nanostructures, have been widely explored [54]. Plant-based insecticides or repellents proved to have a widespectrum of activity against hematophagous arthropods and to be highly safe [15]. Several plants (i.e., more than 2000) have a potential insecticidal effect; however, the properties of just a few of these were explored. Up-to-date plant-based insecticides represent only $1 \%$ of the world's pesticide market.

A recent study, corroborated by the findings herein reported, demonstrated that the majority of these "green chemistry" products were tested on mosquitoes (i.e., 668) [30,54], but only a little attention was given to other blood-sucking arthropods. In particular, after consolidating the publications on the toxic and repellent activity of plant-based products against biting midges, black flies, horse and deer flies, stable flies, tsetse flies, lice, bed and kissing bugs, fleas and sand flies-only 106 scientific reports were identified, and only six of which investigated the activity of these products against sand flies [54]. In the present study, considering the so-called "grey literature" revealed more publications on the topic, and a total of 67 scientific reports were identified although only 14 fully satisfied the inclusion criteria proposed. However, it should be noted that in general, the research focused on the development of botanical products against sand flies just started in the recent years [54,55], and as herein reported, an increasing trend in the number of publications has been observed. As reported elsewhere, the growth in the field of botanical insecticide research has been explosive, from only 61 papers in 1980 to 1207 in 2012 [55]. In the same manner, $78.6 \%$ of the studies analyzed systematically in the present study were conducted between 2001-2017. This increased interest in botanical products corresponds to an increasing need for an alternative to chemical products. However, many factors that could, in some way, limit the study of natural products against the adult stages of sand flies persist. The major limitation is probably the difficulties of maintenance and availability of sand fly colonies [47]; this last finding could explain the limited number of scientific reports that investigate the toxicity and the repellence of botanical product against adult stages of sand flies.

It is thus not surprising that the majority of the analyzed studies herein reported were conducted in countries with a high incidence of visceral and cutaneous human leishmaniosis such as Brazil, India, and Ethiopia [1,56], where the use of botanical products is inherent in the cultural tradition $[13,39]$.

India, China, and Brazil have been defined as the 'big 3' in the research of botanical insecticides [55]. In fact, these three nations produced the greatest number of publications on plant-based products (i.e., the $40.9 \%$ of botanical insecticide articles published in 2012). However, in the present study, no scientific publication produced in China has been identified. This last finding could be related to the fact that leishmaniosis is a sanitary problem controlled in most provinces in China, and it remains fundamentally uncontrolled only in some northwestern provinces and autonomous regions (i.e., Sichuan Province, 
Gansu Province, and the Xinjiang Uygur Autonomous Region) [57]. With regard to the research on botanical products against sand flies, it is important to mention, along with the 'big 3', the research activity produced in some African (Ethiopia and Kenya) [41,50,51] and Middle Eastern countries (Iran) [47]; on the other hand, the number of articles from developed countries is negligible, with only one report found in Europe (i.e., Italy) [46]. The absence of scientific reports produced in Europe may be due to a lesser extent to the scarce use of products of natural origin, and primarily to the fact that in southern Europe, leishmaniosis is mainly a health problem in dogs. The use of repellents or insecticides of natural origin on dogs is limited by many factors such as the smell and the period of effectiveness (i.e., from 30 min to a few hours) of these products, as well as the compliance of the owner.

It is worth noting that the choice of botanical product is related to the availability of the plant in the surroundings; in fact, in different studies, the herbs were taken directly from the fields and the essential oils/or extracts were produced in the laboratory. On the other hand, it is evident that the choice of the product was mainly influenced by the sand fly species. Neem oil, or A. indica, was the main plant tested in both Africa and Asia against the sand fly that belongs to the Phlebotomus genus (i.e., Ph. orientalis, Ph. papatasi and $P h$. bergeroti) $[38,44,45,50]$. The $A$. indica essential oil at $2 \%$ or $5 \%$ has been widely used as an ethnic low-cost alternative protection against sand fly bites, particularly in regions where insecticides are not applied for administrative and economic motivations. It has been shown that the oil at both $2 \%$ and at $5 \%$ is protective against bites of female sand flies. Its efficacy was proven to be higher for $\mathrm{Ph}$. argentipes than against $\mathrm{Ph}$. papatasi, representing the main vector of visceral and cutaneous leishmaniasis in India [44,45]. Similar efficacy was demonstrated for Ph. orientalis and Ph. bergeroti in Ethiopia [50].

Particularly noteworthy is the fact that only one scientific report investigates the repellent effect of lemongrass against $P h$. dubosqui [51]. The extract of this last plant has been widely used as a repellent against mosquitoes in different formulations (i.e., spray, oils, and candles) [58-60].

In contrast to the sand flies belonging to the genus Lutzomyia, there are different plant-based products that have been tested, most of which were based on essential oils or extracts of plants that belong to the Asteraceae family $[39,42,43]$, and to a lesser extent to the Myrtaceae family $[39,40]$. However, the only products that in some way showed promising results were the $A$. ovata aqueous extract [39] against Lu. Longipalpis, and the M. greenmaniana essential oil against Lu. migonei [42]. The other botanical products showed a low or no efficacy.

Independently of the botanical products investigated, the majority of the studies were focused on essential oils, that is, as already observed for other vectors as mosquitoes [30-37] and ticks $[25,26,29]$. Essential oils were the formulation that provided the more interesting results. This formulation, in the majority of the studies herein reported, reaches an efficacy of up to $100 \%$ [40-43], while the amount of protection time it offers against sand fly bites was longer when compared to other formulations (i.e., crude plants extract).

Unfortunately, as stated elsewhere for mosquitoes [55], only a few studies have simultaneously compared the effects of botanical and synthetic products [47]. Therefore, making a real comparison between botanical and synthetic products is not easy as the insecticide and repellent effects of a given product could be related to multiple factors related to the compound (i.e., active ingredients, formulation, mode of application), to environmental factors (i.e., temperature, humidity, and wind), to the hosts (i.e., the attractiveness of individual people to insects), and the insect strain (i.e., the sensitivity of the insects to repellents, biting density) [51].

In our opinion, data on the insecticide and repellent efficacy of botanicals should be critically examined when not compared with control groups consisting of synthetic analogues. For example, the myrtle essential oil showed a repellency of $62.2 \%$ against Ph. papatasi, which could be considered a good result, although the same sand fly strain was more susceptible to diethyl-m-toluamide (i.e., 87\%) [47]. 
The data herein analyzed suggests that plant-based products used as insecticides should be a promising alternative in theory, but the lack of field studies makes it difficult to say whether they are a real alternative to chemical products.

On the contrary, considering the repellent properties of these compounds considerably changes the scenario; in fact, these products, although they show a repellent activity that have reached excellent results in some cases, have a rather short duration. In particular, the repellency of these products lasted only a few hours (i.e., up to a maximum of nine hours) [50] and this short duration of activity greatly limits its real use, especially if we consider the field of veterinary medicine. In fact, in the management of a serious disease such as canine leishmaniasis, nothing can be left to chance. The use of natural repellents would mean applying these products very often on the coat of the animal, which would require a high compliance of the owner.

Furthermore, to the best of our knowledge, there are no data in the literature on the safety of the repeated application of these products on dogs and/or on human skin. Indeed, there is a need for a valid alternative to insecticides and synthetic repellents; however, the road to identifying a botanical alternative is still long.

\section{Conclusions}

The current review suggests that although there is a rapidly growing body of literature on botanical insecticides and repellents against the sand fly species vectors of Leishmania spp., much of this literature is limited to in vitro studies conducted in laboratory conditions. Most of the studies were focused on the insecticide effect of plant-based products; environmental treatment against adult sand flies as well as the control of immature sand flies are considered unpractical stages as they have a transitory effect and are unsustainable in the long term due to several technical and economic reasons $[4,7]$. To date, the sole strategy recognized for the prevention of leishmaniosis is the use of topical repellent compounds; as underlined herein, only a few studies investigated the repellency of plant-based products, and these studies highlighted that natural compounds demonstrate a repellent function for a really short period of time, which could significantly limit their sustainability and use under normal conditions. The road is still long before we can say that there is a natural alternative to chemical-based repellents. Therefore, although alternatives to synthetic products are needed, a large amount of preliminary studies still need to be performed before a valid natural alternative could be formulated.

Author Contributions: Conceptualization, E.N.; methodology, E.N. and M.P.; validation, A.P., E.B., and G.G.; formal analysis, E.N.; investigation, E.N.; data curation, E.N. and M.P.; writing-original draft preparation, E.N. and M.P.; writing-review and editing, A.P., E.B., and G.G.; supervision, A.P. All authors have read and agreed to the published version of the manuscript.

Funding: This research received no external funding.

Institutional Review Board Statement: Ethical review and approval were waived for this study as they are not applicable.

Informed Consent Statement: Not applicable for this type of study.

Data Availability Statement: All data associated with this study can be obtained from the corresponding author on reasonable request.

Conflicts of Interest: The authors declare no conflict of interest.

\section{References}

1. World Health Organization. Control of the Leishmaniases: Report of a Meeting of the WHO Expert Committee on the Control of Leishmaniases, Geneva, 22-26 March 2010. Available online: https:/ /apps.who.int/iris/handle/10665/44412 (accessed on 16 May 2021).

2. Killick-Kendrick, R. The biology and control of phlebotomine sand flies. Clin. Dermatol. 1999, 17, 279-289. [CrossRef] 
3. Gaglio, G.; Brianti, E.; Napoli, E.; Falsone, L.; Dantas-Torres, F.; Tarallo, V.D.; Otranto, D.; Giannetto, S. Effect of night timeintervals, height of traps and lunar phases on sand fly collection in a highly endemic area for canine leishmaniasis. Acta Trop. 2014, 133, 73-77. [CrossRef] [PubMed]

4. Maroli, M.; Mizzon, V.; Siragusa, C.; D’Oorazi, A.; Gradoni, L. Evidence for an impact on the incidence of canine leishmaniasis by the mass use of deltamethrin-impregnated dog collars in southern Italy. Med. Vet. Entomol. 2001, 15, 358-563. [CrossRef] [PubMed]

5. Abbate, J.M.; Arfuso, F.; Napoli, E.; Gaglio, G.; Giannetto, S.; Latrofa, M.S.; Otranto, D.; Brianti, E. Leishmania infantum in wild animals in endemic areas of southern Italy. Comp. Immunol. Microbiol. Infect. Dis. 2019, 67, 101374. [CrossRef]

6. Gramiccia, M. Recent advances in leishmaniosis in pet animals: Epidemiology, diagnostics and anti-vectorial prophylaxis. Vet. Parasitol. 2011, 181, 23-30. [CrossRef]

7. Otranto, D.; Dantas-Torres, F. The prevention of canine leishmaniasis and its impact on public health. Trends Parasitol. 2013, 29, 339-345. [CrossRef] [PubMed]

8. Dantas-Torres, F.; Chomel, B.B.; Otranto, D. Ticks and tick-borne diseases: A One Health perspective. Trends Parasitol. 2012, 28, 437-446. [CrossRef] [PubMed]

9. Debboun, M.; Strickman, D. Insect repellents and associated personal protection for a reduction in human disease. Med. Vet. Entomol. 2013, 27, 1-9. [CrossRef]

10. Jaramillo Ramirez, G.I.; Logan, J.G.; Loza-Reyes, E.; Stashenko, E.; Moores, G.D. Repellents inhibit P450 enzymes in Stegomyia (Aedes) aegypti. PLoS ONE 2012, 7, 48698. [CrossRef]

11. Nentwig, G. Use of repellents as prophylactic agents. Parasitol. Res. 2003, 90, S40-S48. [CrossRef]

12. Islam, J.; Zaman, K.; Duarah, S.; Raju, P.S.; Chattopadhyay, P. Mosquito repellents: An insight into the chronological perspectives and novel discoveries. Acta Trop. 2017, 167, 216-230. [CrossRef]

13. Seyoum, A.; Pålsson, K.; Kung'a, S.; Kabiru, E.W.; Lwande, W.; Killeen, G.F.; Hassanali, A.; Knols, B.G. Traditional use of mosquito-repellent plants in western Kenya and their evaluation in semi-field experimental huts against Anopheles gambiae: Ethnobotanical studies and application by thermal expulsion and direct burning. Trans. R. Soc. Trop. Med. Hyg. 2002, 96, 225-231. [CrossRef]

14. Tiwari, T.N.; Varma, J.; Dubey, N.K.; Chansouria, J.P.; Ali, Z. Pharmacological evaluation of some bioactive plant products on albino rats. Hindustan Antibiot. Bull. 1998, 40, 38-41.

15. Dinesh, D.S.; Kumari, S.; Kumar, V.; Das, P. The potentiality of botanicals and their products as an alternative to chemical insecticides to sandflies (Diptera: Psychodidae): A review. J. Vector Borne Dis. 2014, 51, 1-7. [PubMed]

16. Curtis, S.K. Evaluation of the control of Myobia musculi infestations on laboratory mice with permethrin. Lab. Anim. Sci. 1990, $40,463$.

17. Mnif, W.; Hassine, A.I.; Bouaziz, A.; Bartegi, A.; Thomas, O.; Roig, B. Effect of endocrine disruptor pesticides: A review. Int. J. Environ. Res. Public Health 2011, 8, 2265-2303. [CrossRef]

18. Channa, K.; Rollin, H.B.; Nost, T.H.; Odland, J.O.; Sandanger, T.M. Prenatal ex- posure to DDT in malaria endemic region following indoor residual spraying and in non-malaria coastal regions of South Africa. Sci. Total Environ. 2012, 429, 183-190. [CrossRef]

19. Madden, A.H.; Lindquist, A.W.; Longcoy, O.M.; Knipling, E.F. Control of Adult Sand Flies by Airplane Spraying with DDT. Fla. Entomol. 1946, 29, 5-10. [CrossRef]

20. Coleman, M.; Foster, G.M.; Deb, R.; Pratap Singh, R.; Ismail, H.M.; Shivam, P.; Ghosh, A.K.; Dunkley, S.; Kumar, V.; Coleman, M.; et al. DDT-based indoor residual spraying suboptimal for visceral leishmaniasis elimination in India. Proc. Natl. Acad. Sci. USA 2015, 112, 8573-8578. [CrossRef] [PubMed]

21. Moore, M.T.; Lizotte, R.E., Jr.; Smith, S., Jr. Responses of Hyalella azteca to a pyrethroid mixture in a constructed wetland. Bull. Environ. Contam. Toxicol. 2007, 78, 245-248. [CrossRef]

22. Kitchen, L.W.; Lawrence, K.L.; Coleman, R.E. The role of the United States military in the development of vector control products, including insect repellents, insecticides, and bed nets. J. Vector Ecol. 2009, 34, 50-61. [CrossRef] [PubMed]

23. Alexander, B.; Usma, M.C.; Cadena, H.; Quesada, B.L.; Solarte, Y.; Roa, W.; Montoya, J.; Jaramillo, C.; Travi, B.L. Phlebotomine sandflies associated with a focus of cutaneous leishmaniasis in Valle del Cauca, Colombia. Med. Vet. Entomol. 1995, 9, $273-278$. [CrossRef] [PubMed]

24. Majori, G.; Maroli, M.; Sabatinelli, G.; Fausto, A.M. Efficacy of permethrin-impregnated curtains against endophilic phlebotomine sandflies in Burkina Faso. Med. Vet. Entomol. 1989, 3, 441-444. [CrossRef]

25. Ellse, L.; Sands, B.; Burden, F.A.; Wall, R. Essential oils in the management of the donkey louse, Bovicola ocellatus. Equine Vet. J. 2016, 48, 285-289. [CrossRef] [PubMed]

26. Nerio, L.S.; Olivero-Verbel, J.; Stashenko, E. Repellent activity of essential oils: A review. Bioresour. Technol. 2010, 101, 372-378. [CrossRef] [PubMed]

27. Kolaczinski, J.H.; Curtis, C.F. Chronic illness as a result of low-level exposure to synthetic pyrethroid insecticides: A review of the debate. Food Chem. Toxicol. 2004, 42, 697-706. [CrossRef]

28. Ramwell, C.T.; Heather, A.I. Shepherd AJ. Herbicide loss following application to a railway. Pest. Manag. Sci. 2004, 60, 556-564. [CrossRef] 
29. Lee, J.K.; Stokes, J.V.; Moraru, G.M.; Harper, A.B.; Smith, C.L.; Wills, R.W.; Varela-Stokes, A.S. Transmission of Amblyomma maculatum-Associated Rickettsia spp. During Cofeeding on Cattle. Vector Borne Zoonotic Dis. 2018, 18, 511-518. [CrossRef]

30. Pavela, R.; Maggi, F.; Iannarelli, R.; Benelli, G. Plant extracts for developing mosquito larvicides: From laboratory to the field, with insights on the modes of action. Acta Trop. 2019, 193, 236-271. [CrossRef]

31. Tisgratog, R.; Sanguanpong, U.; Grieco, J.P.; Ngoen-Kluan, R.; Chareonviriyaphap, T. Plants traditionally used as mosquito repellents and the implication for their use in vector control. Acta Trop. 2016, 157, 136-144. [CrossRef] [PubMed]

32. Chattopadhyay, P.; Dhiman, S.; Borah, S.; Rabha, B.; Chaurasia, A.K.; Veer, V. Essential oil based polymeric patch development and evaluating its repellent activity against mosquitoes. Acta Trop. 2015, 147, 45-53. [CrossRef] [PubMed]

33. Rehman, J.U.; Ali, A.; Khan, I.A. Plant based products: Use and development as repellents against mosquitoes: A review. Fitoterapia 2014, 95, 65-74. [CrossRef]

34. Kongkaew, C.; Sakunrag, I.; Chaiyakunapruk, N.; Tawatsin, A. Effectiveness of citronella preparations in preventing mosquito bites: Systematic review of controlled laboratory experimental studies. Trop. Med. Int. Health 2011, 16, 802-810. [CrossRef] [PubMed]

35. Shaalan, E.A.; Canyon, D.; Younes, M.W.; Abdel-Wahab, H.; Mansour, A.H. A review of botanical phytochemicals with mosquitocidal potential. Environ. Int. 2005, 31, 1149-1166. [CrossRef]

36. Omolo, M.O.; Okinyo, D.; Ndiege, I.O.; Lwande, W.; Hassanali, A. Repellency of essential oils of some Kenyan plants against Anopheles gambiae. Phytochemistry 2004, 65, 2797-2802. [CrossRef] [PubMed]

37. Pålsson, K.; Jaenson, T.G. Plant products used as mosquito repellents in Guinea Bissau, West Africa. Acta Trop. 1999, 72, 39-52. [CrossRef]

38. Srinivasan, R.; Kalyanasundaram, M. Relative efficacy of DEPA and neem oil for repellent activity against Phlebotomus papatasi, the vector of leishmaniasis. J. Commun. Dis. 2001, 33, 180-184. [PubMed]

39. Luitgards-Moura, J.F.; Castellon Bermudez, E.G.; Rocha, A.F.; Tsouris, P.; Rosa-Freitas, M.G. Preliminary assays indicate that Antonia ovata (Loganiaceae) and Derris amazonica (Papilionaceae), ichthyotoxic plants used for fishing in Roraima, Brazil, have an insecticide effect on Lutzomyia longipalpis (Diptera: Psychodidae: Phlebotominae). Mem. Inst. Oswaldo Cruz 2002, 97, 737-742. [CrossRef] [PubMed]

40. Maciel, M.V.; Morais, S.M.; Bevilaqua, C.M.; Silva, R.A.; Barros, R.S.; Sousa, R.N.; Sousa, L.C.; Brito, E.S.; Souza-Neto, M.A. Chemical composition of Eucalyptus spp. essential oils and their insecticidal effects on Lutzomyia longipalpis. Vet. Parasitol. 2010, 20, 1-7. [CrossRef]

41. Ireri, L.N.; Kongoro, J.; Ngure, P.; Mutai, C.; Langat, B.; Tonui, W.; Kimutai, A.; Mucheru, O. The potential of the extracts of Tagetes minuta Linnaeus (Asteraceae), Acalypha fruticosa Forssk (Euphorbiaceae) and Tarchonanthus camphoratus L. (Compositae) against Phlebotomus duboscqi Neveu Lemaire (Diptera: Psychodidae), the vector for Leishmania major Yakimoff and Schokhor. J. Vector Borne Dis. 2010, 47, 168-174.

42. Cárdenas, J.; Rojas, J.; Rondón, M.; Nieves, E. Adulticide effect of Monticalia greenmaniana (Asteraceae) against Lutzomyia migonei (Diptera: Psychodidae). Parasitol. Res. 2012, 111, 787-794. [CrossRef]

43. Torres, L.; Rojas, J.; Rondón, M.; Morales, A.; Nieves, E. Insecticide Activity of Ageratina jahnii and Ageratina pichinchensis (Asteraceae) against Lutzomyia migonei (Diptera: Psychodidae). Adv. Biomed. Res. 2017, 2, 53.

44. Sharma, V.P.; Dhiman, R.C. Neem oil as a sand fly (Diptera: Psychodidae) repellent. J. Am. Mosq. Control. Assoc. 1993, 9, 364-366.

45. Srinivasan, R.; Kalyanasundaram, M. Comparative efficacy of Neem oil and DEPA in repelling sandfly, Phlebotomus papatasi, the vector of cutaneous Leishmaniasis. In Proceedings of the Ist International Seminar on Medical Entomology, Bhopal, India, 19-20 January 2003.

46. Valerio, L.; Maroli, M. Valutazione dell'effetto repellente ed anti-feeding dell'olio d'aglio (Allium sativum) nei confronti dei flebotomi (Diptera: Psychodidae) [Evaluation of repellent and anti-feeding effect of garlic oil (Allium sativum) against the bite of phlebotomine sandflies Diptera: Psychodidae]. Ann. Ist. Super Sanita 2005, 41, 253-256.

47. Yaghoobi-Ershadi, M.R.; Akhavan, A.; Jahanifard, E.; Vatandoost, H.; Amin, G.; Moosavi, L.; Zahraei Ramazani, A.R.; Abdoli, H.; Arandian, M.H. Repellency Effect of Myrtle Essential Oil and DEET against Phlebotomus papatasi, under Laboratory Conditions. Iran. J. Public Health 2006, 35, 7-13.

48. Nieves, E.; Fernández Méndez, J.; Lias, J.; Rondón, M.; Briceño, B. Actividad repelente de aceites esenciales contra las picaduras de Lutzomyia migonei (Diptera: Psychodidae) [Repellent activity of plant essential oils against bites of Lutzomyia migonei (Diptera: Psychodidae)]. Rev. Biol. Trop. 2010, 58, 1549-1560.

49. Rojas, E.; Scorza, J.V. The use of lemon essential oil as a sandfly repellent. Trans. R. Soc. Trop. Med. Hyg. 1991, 85, 803. [CrossRef]

50. Kebede, Y.; Gebre-Michael, T.; Balkew, M. Laboratory and field evaluation of neem (Azadirachta indica A. Juss) and Chinaberry (Melia azedarach L.) oils as repellents against Phlebotomus orientalis and P. bergeroti (Diptera: Psychodidae) in Ethiopia. Acta Trop. 2010, 113, 145-150. [CrossRef] [PubMed]

51. Kimutai, A.; Ngeiywa, M.; Mulaa, M.; Njagi, P.G.; Ingonga, J.; Nyamwamu, L.B.; Ombati, C.; Ngumbi, P. Repellent effects of the essential oils of Cymbopogon citratus and Tagetes minuta on the sandfly, Phlebotomus duboscqi. BMC Res. Notes 2017, 10, 98. [CrossRef] [PubMed]

52. Hicks, S.; Wang, M.; Doraiswamy, V.; Fry, K.; Wohlford, E.M. Neurodevelopmental delay diagnosis rates are increased in a region with aerial pesticide application. Front. Pediatr. 2017, 5, 116. [CrossRef] 
53. Silver, M.K.; Shao, J.; Zhu, B.; Chen, M.; Xi, Y.; Kaciroti, N.; Lozoff, B.; Meeker, J.D. Prenatal naled and chlorpyrifos exposure is associated with deficits in infant motor function in a cohort of Chinese infants. Environ. Int. 2017, 106, 248-256. [CrossRef] [PubMed]

54. Benelli, G.; Pavela, R. Repellence of essential oils and selected compounds against ticks-A systematic review. Acta Trop. 2018, 179, 47-54. [CrossRef]

55. Isman, M.B.; Grieneisen, M.L. Botanical insecticide research: Many publications, limited useful data. Trends Plant. Sci. 2014, 19, 140-145. [CrossRef] [PubMed]

56. Gebremichael Tedla, D.; Bariagabr, F.H.; Abreha, H.H. Incidence and Trends of Leishmaniasis and Its Risk Factors in Humera, Western Tigray. J. Parasitol. Res. 2018, 24, 8463097. [CrossRef]

57. Zheng, C.; Wang, L.; Li, Y.; Zhou, X.N. Visceral leishmaniasis in northwest China from 2004 to 2018: A spatio-temporal analysis. Infect. Dis. Poverty 2020, 3, 165. [CrossRef] [PubMed]

58. Solomon, B.; Gebre-Mariam, T.; Asres, K. Mosquito repellent actions of the essential oils of Cymbopogon citratus, Cymbopogon nardus and Eucalyptus citriodora: Evaluation and formulation studies. J. Essent. Oil Bear. Plants 2012, 15, 766-773. [CrossRef]

59. Moore, S.J.; Hill, N.; Ruiz, C.; Cameron, M.M. Field evaluation of tradition- ally used plant-based repellents and fumigants against the malaria vector Anopheles darlingi in Riberalta, Bolivian Amazon. J. Med. Entomol. 2007, 44, 624-630. [CrossRef]

60. Trongtokit, Y.; Rongsriyam, Y.; Komalamisra, N.; Apiwathnasorn, C. Comparative repellency of 38 essential oils against mosquito bites. Phytother. Res. 2005, 19, 303-309. [CrossRef] 